was provided by Roche and Chugai and performed by Ecron Acunova GmbH, Germany.

Disclosure of Interest: C. Specker Grant/research support from: Chugai, DRFZ, Consultant for: Abbvie, Janssen, Chugai, MSD, Novartis, UCB, Lilly, Boehringer, Speakers bureau: Abbvie, Celgene, Chugai, Euroimmun, MSD, Pfizer, UCB, H. Kellner: None declared, P. Kästner: None declared, C. Volberg: None declared, V. Braunewell: None declared, I. Schwarze: None declared, M. Aringer: None declared, M. Sieburg: None declared, M. Hofmann Employee of: Chugai Pharma Europe Ltd., Zweigniederlassung Deutschland, J. Flacke Employee of: Roche Pharma AG, Germany, H.-P. Tony Consultant for: Roche Pharma, Abbvie, BMS, Chugai, Janssen, Novartis, Pfizer, Sanofi, Lilly, MSD, Astra-Zeneca, G. Fliedner: None declared

DOI: 10.1136/annrheumdis-2017-eular.5876

\section{SAT0194 SIRUKUMAB INTEGRATED SAFETY IN RHEUMATOID ARTHRITIS PATIENTS: ANALYSIS OF THE SIRROUND PHASE 3 DATA}

D. Aletaha ${ }^{1}$, C. Thorne ${ }^{2}$, M. Schiff ${ }^{3}$, M. Harigai ${ }^{4}$, R. Rao ${ }^{5}$, N. Goldstein ${ }^{6}$, B. Cheng ${ }^{6}$, C. Cohen ${ }^{7}$, B. Hsu ${ }^{6}$, K. Brown ${ }^{7} .{ }^{1}$ Medical University of Vienna, Vienna, Austria; ${ }^{2}$ University of Toronto and Southlake Regional Health Centre, Newmarket, ON, Canada: ${ }^{3}$ University of Colorado School of Medicine, Denver, CO, United States; ${ }^{4}$ Tokyo Women's Medical University, Tokyo, Japan; ${ }^{5}$ GSK Medicines Research Centre, Hertfordshire, United Kingdom; ${ }^{6}$ Janssen Research \& Development, LLC, Spring House, PA; ${ }^{7}$ GlaxoSmithKline, Collegeville, PA, United States

Background: Sirukumab (SIR), a human monoclonal antibody that selectively binds the IL- 6 cytokine, is in development for the treatment of rheumatoid arthritis (RA). Efficacy of SIR was shown in several phase 3 trials in RA patients (pts; SIRROUND program).

Objectives: To analyze safety data from completed/ongoing studies in the SIRROUND program

Methods: Safety comparisons included SIR $50 \mathrm{mg} \mathrm{q4w}$ and $100 \mathrm{mg} \mathrm{q} 2 \mathrm{w}$ doses vs placebo (pbo) in the pbo-controlled period (Wk $0-18$ ) of 2 phase 3 studies. A long-term comparison of the safety of SIR $50 \mathrm{mg} \mathrm{q} 4 \mathrm{w}$ and $100 \mathrm{mg}$ q2w for the entire program was also performed.

Results: In phase 3 studies, 2926 pts received SIR for up to $3.4 y$ (median duration, 1.46y). During Wk $0-18$, there were more adverse events (AEs), AEs leading to discontinuation, and serious AEs (SAEs) with SIR vs pbo, with cumulative rates of SAEs remaining constant over time (Table). In general, no dose effect with SIR was observed in the 18-wk or long-term analysis. Mortality rates were similar across treatment groups through 18 wks and remained stable in long-term analysis. Serious infections were more frequent in SIR-treated pts vs pbo during Wk $0-18$, with similar rates through long-term analysis. Rates of gastrointestinal (Gl) perforations and malignancies were low and similar across groups during the 18-wk and long-term analysis; major adverse cardiovascular event (MACE) rates were similar through 18 wks and numerically higher with SIR $50 \mathrm{mg}$ q $4 \mathrm{w}$ vs $100 \mathrm{mg}$ q2w in long-term analysis.

Conclusions: SIR is well tolerated in pts with moderately to severely active RA. Overall, no dose relationship was observed between SIR 50mg q4w and 100mg q2w for types or frequencies of $A E s$.

Disclosure of Interest: D. Aletaha Grant/research support from: AbbVie, Pfizer, Grünenthal, Merck Medac, UCB, Mitsubishi/Tanabe, Janssen, and Roche, Consultant for: AbbVie, Pfizer, Grünenthal, Merck Medac, UCB, Mitsubishi/Tanabe, Janssen, and Roche, C. Thorne Grant/research support from: AbbVie, Amgen, Celgene, Lilly, Novartis, Pfizer, Sanofi, and UCB, Consultant for: AbbVie, Amgen, Celgene, Centocor, Genzyme, Hospira, Janssen, Lilly, Medexus/Medac, Merck, Novartis, Pfizer, Sanofi, and UCB, Speakers bureau: Medexus/Medac, M. Schiff Consultant for: AbbVie, Bristol-Myers Squibb, Eli Lilly, Johnson \& Johnson, UCB, Speakers bureau: AbbVie, M. Harigai Grant/research support from: AbbVie Japan, Astellas Pharma, Bristol-Myers Squibb, Chugai Pharmaceutical, Eisai, Mitsubishi Tanabe Pharma, Ono Pharmaceuticals, Santen Pharmaceutical, Takeda Pharmaceutical, UCB Japan, Teijin Pharma, Consultant for: AbbVie Japan, Janssen Pharma, Chugai Pharmaceutical, Teijin Pharma, Eli Lilly Japan, and Zenyaku Kogyo, R. Rao Shareholder of: GlaxoSmithKline, Employee of: GlaxoSmithKline, N. Goldstein Employee of: Janssen Research \& Development, LLC, B. Cheng Shareholder of: Janssen Research \& Development, LLC, Employee of: Janssen Research \& Development, LLC, C. Cohen Employee of: GlaxoSmithKline, B. Hsu Shareholder of: Janssen Research \& Development, LLC, Employee of: Janssen Research \& Development, LLC, K. Brown Shareholder of: GlaxoSmithKline, Employee of: GlaxoSmithKline

DOI: 10.1136/annrheumdis-2017-eular.5176

\section{SAT0195 RITUXIMAB SHOWS BETTER SUSTAINABILITY THAN TNF INHIBITORS WHEN USED FOLLOWING INITIAL BIOLOGIC DMARD FAILURE IN THE TREATMENT OF RHEUMATOID ARTHRITIS: 8 YEARS OF REAL-WORLD OBSERVATIONS FROM THE RHUMADATA ${ }^{\circledR}$ CLINICAL DATABASE AND REGISTRY}

D. Choquette $^{1}$, L. Bessette ${ }^{2}$, B. Haraoui ${ }^{1}$, F. Massicotte ${ }^{1}$, J.-P. Pelletier ${ }^{1}$, J.-P. Raynauld ${ }^{1}$, M.-A. Rémillard ${ }^{1}$, D. Sauvageau ${ }^{1}$, A. Turcotte $^{2}$, É. Villeneuve ${ }^{1}$, L. Coupal ${ }^{1} .{ }^{1}$ Rheumatology, Institut de recherche en rhumatologie de Montréal (IRRM), Montréal; ${ }^{2}$ Rheumatology, Centre d'ostéoporose et de rhumatologie de Québec (CORQ), Québec, Canada

Background: In the absence of biomarkers predicting response to a specific therapy, the choice of second biologic is based mostly on habit and availability of an alternative agent. Traditionally, a second anti-TNF was the preferred option,

Abstract SAT0194 - Table 1. Treatment-emergent AEs in Phase 3 Studies

\begin{tabular}{|c|c|c|c|c|c|}
\hline \multirow[b]{2}{*}{ Ine } & \multicolumn{3}{|c|}{ Wk 0-18 } & \multicolumn{2}{|c|}{ Long-term analysis (Wk 0-safety cutoff) } \\
\hline & $\mathrm{Pbo}(\mathrm{N}=850)$ & SIR 50mg q4w (N=848) & SIR 100mg q2w $(\mathrm{N}=850)$ & SIR 50mg q4w $(\mathrm{N}=1461)$ & SIR 100mg q2w $(\mathrm{N}=1465)$ \\
\hline AEs, n (\%) & $444(52.2)$ & $515(60.7)$ & $548(64.5)$ & $1207(82.6)$ & $1237(84.4)$ \\
\hline AEs leading to discontinuation, $\mathrm{n}(\%)$ & $22(2.6)$ & $34(4.0)$ & $45(5.3)$ & $174(11.9)$ & $196(13.4)$ \\
\hline SAEs, n (\%) & $27(3.2)$ & $41(4.8)$ & $46(5.4)$ & $265(18.1)$ & $268(18.3)$ \\
\hline Incidence* & $9.36(6.17-13.61)$ & $14.36(10.30-19.48)$ & $16.14(11.82-21.53)$ & $13.12(11.58-14.79)$ & $13.12(11.60-14.79)$ \\
\hline Serious infection, $\mathrm{n}(\%)$ & $7(0.8)$ & $16(1.9)$ & $14(1.6)$ & $102(7.0)$ & $101(6.9)$ \\
\hline Incidence* & $2.40(0.97-4.95)$ & $5.52(3.15-8.96)$ & $4.81(2.63-8.07)$ & $4.76(3.88-5.77)$ & $4.67(3.81-5.68)$ \\
\hline Gl perforation, $\mathrm{n}(\%)$ & 0 & $1(0.1)$ & $3(0.4)$ & $5(0.3)$ & $9(0.6)$ \\
\hline Incidence $^{\star}$ & $0(0-1.02)$ & $0.34(0.01-1.91)$ & $1.02(0.21-2.99)$ & $0.23(0.07-0.53)$ & $0.41(0.19-0.77)$ \\
\hline MACE, n (\%) & $2(0.2)$ & $3(0.4)$ & $2(0.2)$ & $20(1.4)$ & $9(0.6)$ \\
\hline Incidence* ${ }^{*}$ & $0.68(0.08-2.47)$ & $1.03(0.21-3.00)$ & $0.68(0.08-2.46)$ & $0.92(0.56-1.42)$ & $0.41(0.19-0.77)$ \\
\hline Malignancy, n (\%) & $2(0.2)$ & $1(0.1)$ & $1(0.1)$ & $23(1.6)$ & $19(1.3)$ \\
\hline Incidence ${ }^{\star}$ & $0.68(0.08-2.47)$ & $0.34(0.01-1.91)$ & $0.34(0.01-1.91)$ & $1.05(0.67-1.58)$ & $0.86(0.52-1.35)$ \\
\hline Death, n (\%) & $1(0.1)$ & $1(0.1)$ & $1(0.1)$ & $15(1.0)$ & $14(1.0)$ \\
\hline Incidence ${ }^{*}$ & $0.34(0.01-1.91)$ & $0.34(0.01-1.91)$ & $0.34(0.01-1.90)$ & $0.68(0.38-1.13)$ & r $0.63(0.35-1.06)$ \\
\hline
\end{tabular}

*Incidence per 100 pt-years $(95 \% \mathrm{Cl})$.

Abstract SAT0195 - Table 1. First bDMARD history and Retention Characteristics of Second bDMARD used

\begin{tabular}{|c|c|c|c|c|c|c|}
\hline \multirow{4}{*}{ First bDMARD Failed } & \multicolumn{6}{|c|}{ Second bDMARD } \\
\hline & \multicolumn{3}{|c|}{ TNFi } & \multicolumn{3}{|c|}{ Rituximab } \\
\hline & \multicolumn{2}{|c|}{ Failure type } & \multirow[t]{2}{*}{ All } & \multicolumn{2}{|c|}{ Failure type } & \multirow[t]{2}{*}{ All } \\
\hline & Primary & Secondary & & Primary & Secondary & \\
\hline TNF inhibitor & $41(25.5 \%)$ & $120(74.5 \%)$ & $161(100.0 \%)$ & $17(28.8 \%)$ & $42(71.2 \%)$ & $59(100.0 \%)$ \\
\hline Other mode of action & $6(18.2 \%)$ & $27(81.8 \%)$ & $33(100.0 \%)$ & $0(0.0 \%)$ & $0(0.0 \%)$ & $0(0.0 \%)$ \\
\hline Total & $47(24.2 \%)$ & $147(75.8 \%)$ & $194(100.0 \%)$ & $17(28.8 \%)$ & $42(71.2 \%)$ & $59(100.0 \%)$ \\
\hline \multicolumn{7}{|c|}{ Second bDMARD Retention Probability at: } \\
\hline 6 Months & & $64.68 \%(3.45 \%)$ & & & $96.15 \%(2.67 \%)$ & \\
\hline 12 Months & & $50.54 \%(3.61 \%)$ & & & $88.05 \%(4.59 \%)$ & \\
\hline 24 Months & & $39.77 \%(3.59 \%)$ & & & $85.84 \%(4.97 \%)$ & \\
\hline 60 Months & & $22.26 \%(3.53 \%)$ & & & $72.44 \%(6.95 \%)$ & \\
\hline 96 Months & & $13.22 \%(3.62 \%)$ & & & $72.44 \%(6.95 \%)$ & \\
\hline \multicolumn{7}{|l|}{ Biologic Retention Time (years) } \\
\hline Mean, mean (SE) & & $2.71(0.25)$ & & & $6.73(0.46)$ & \\
\hline Lower Quartile, $(95 \% \mathrm{Cl})$ & & $0.36(0.28-0.44)$ & & & $4.18(1.51-8.48)$ & \\
\hline Median, $(95 \% \mathrm{Cl})$ & & $1.08(0.71-1.60)$ & & & $-(8.42-)$ & \\
\hline Upper Quartile, $(95 \% \mathrm{Cl})$ & & $4.26(3.25-6.64)$ & & & $-(-)$ & \\
\hline
\end{tabular}


but recent registry data point to better responses and retention if a drug with a different mode of action is prescribed.

Objectives: Assess the long-term retention of rituximab (RTX) and TNFi following first biologic (b)DMARD inadequate response in RHUMADATA ${ }^{\circledR}$ registry patients (pts) with RA

Methods: Data from RHUMADATA ${ }^{\circledR}$ pts with RA prescribed either RTX or TNFi as the second bDMARD after 1 January 2006 were analysed. Pts were followed until treatment discontinuation or 9 January 2017 cut-off. Pt characteristics were compared using descriptive statistics, bDMARD discontinuation rates using Kaplan-Meier methods, and proportional hazard models were used to identify predictors of treatment discontinuation.

Results: Data for 53 and 194 pts prescribed RTX or a TNFi, respectively, as second-line treatment were extracted. No clinically significant differences in baseline characteristics were noted between treatment groups. Most pts were women (74.9\%), average age (SD) was 45.2 (12.9) years at diagnosis and disease duration 10.5 (8.7) years. Most pts were stopping an anti-TNF agent: $100 \%$ of those who were switched to RTX and $83 \%$ of those who were prescribed a second anti-TNF. Overall, $77.3 \%$ of pts stopped their first bDMARD after $>6$ months of treatment (secondary failure). Significant differences in retention between RTX and TNFi groups (log-rank $\mathrm{p} \leq .0001$ ) were observed (Table, Figure). Results remained unchanged for pts treated with TNFi only in first line, and primary/secondary failure of the first bDMARD did not affect sustainability of the second agent. Lack of efficacy (54.4\%) and AEs (16.5\%) were the most commonly cited reasons for treatment discontinuation.

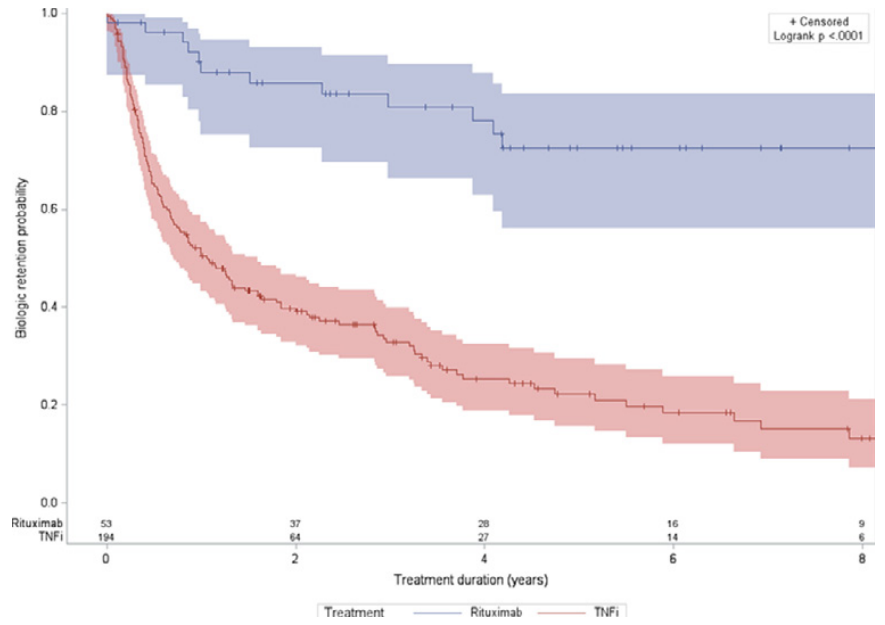

Conclusions: Rituximab has better sustainability over a second line TNFi in RA patients having failed one prior bDMARD.

Disclosure of Interest: D. Choquette Grant/research support from: Roche, Consultant for: Roche, L. Bessette Grant/research support from: Amgen, BMS, Janssen, Roche, UCB, AbbVie, Pfizer, Merck, Celgene, Sanofi, Lilly, Novartis, Consultant for: BMS, Janssen, Roche, UCB, AbbVie, Pfizer, Celgene, Lilly, Novartis, B. Haraoui Grant/research support from: BMS, Janssen, Roche, Consultant for: Abbvie, Amgen, BMS, Celgene, Janssen, Merck, Pfizer, Roche, Sandoz, UCB, Speakers bureau: Pfizer, UCB, F. Massicotte: None declared, J.-P. Pelletier: None declared, J.-P. Raynauld Speakers bureau: AbbVie, Amgen, BMS, Janssen, Pfizer, Roche, Sanofi, Novartis, UCB, M.-A. Rémillard: None declared, D. Sauvageau: None declared, A. Turcotte Consultant for: Amgen, Abbvie, BMS, Celegene, Janssen, Roche, Pfizer, Lilly, Novartis, Merck, Sanofi, UCB, Speakers bureau: Amgen, Abbvie, BMS, Celegene, Janssen, Roche, Pfizer, Lilly, Novartis, Merck, É. Villeneuve Consultant for: Celgene, Cimzia, Pfizer, Speakers bureau: Abbvie, Roche, BMS, L. Coupal: None declared

DOI: 10.1136/annrheumdis-2017-eular.6361

\section{SAT0196 REPEATED RITUXIMAB INFUSIONS FOR THE THERAPY OF RHEUMATOID ARTHRITIS IS NOT ASSOCIATED WITH INCREASED RATES OF SERIOUS INFECTIONS}

D.A. Pappas $^{1,2}$, G.W. Reed ${ }^{2,3}$, S. Zlotnick ${ }^{4}$, J. Best ${ }^{4}$, R. Magner ${ }^{3}$, G. Persuitte $^{2}$, J. Greenberg 2,5 . ' Columbia University, New York, NY; ${ }^{2}$ Corrona, LLC, Southborough, MA; ${ }^{3}$ University of Massachusetts Medical School, Worcester, $M A ;{ }^{4}$ Genentech, Inc., South San Francisco, CA; ${ }^{5}$ New York University School of Medicine, New York, NY, United States

Background: Extended observations in clinical trials have not demonstrated an increased risk of serious infection events (SIE) in patients with rheumatoid arthritis (RA) treated with rituximab. ${ }^{1}$ However, continuous surveillance using large-scale observational data is of importance.

Objectives: To evaluate the rate of SIEs among patients with RA who received only an initial rituximab infusion vs those retreated with $\geq 1$ rituximab infusion during the first year of therapy, and also to describe characteristics of rituximabtreated patients who experienced an SIE vs those who did not.

Methods: Patients with RA enrolled in the Corrona registry and treated with rituximab were followed until their most recent Corrona registry visit, first SIE, switch to another biologic or targeted synthetic disease-modifying antirheumatic drug, or 12 months after the most recent infusion with no further retreatment whichever occurred first. The rate of SIEs was estimated in the overall population as well as in patients retreated with $\geq 1$ infusion every 12 months after rituximab initiation and in those who did not receive a repeat infusion in the first 12 months. Patient characteristics were compared between those who experienced an SIE and those who did not.

Results: A total of 1361 patients with 1821 patient-years (PY) of follow-up were included; there were 59 SIEs for a rate of 3.24 SIE/100 PYs. 637 patients $(46.8 \%)$ received $\geq 1$ rituximab retreatment during the first 12 months and 724 (53.2\%) received only the initial infusion. In the retreatment population there were 40 SIEs per 1312.8 PY for a rate $(95 \% \mathrm{Cl})$ of $3.05 / 100 \mathrm{PY}(2.18-4.15)$, and in the no retreatment population there were 19 SIEs per $508.71 \mathrm{PY}$ for a rate $(95 \% \mathrm{Cl})$ of 3.73/100 PY (2.25-5.83). The Kaplan-Meier curve depicting the occurrence of SIEs in the 2 cohorts during the first year of follow-up is shown (Figure). In the 59 patients $(4.3 \%)$ who experienced an SIE, the mean (SD) number of rituximab infusions was $1.88(1.18)$, compared with $2.07(1.70)$ in the 1302 patients $(95.7 \%)$ who did not experience an SIE. Patients who experienced an SIE vs those who did not were older (mean age [SD]: 62.9 [9.9] vs 58.1 [12.55] years), had longer disease duration (19.1 [13.1] vs 13.6 [10.4] years), were more frequently diabetic (16.9\% vs $8.3 \%)$ and more frequently had cardiovascular disease $(25.4 \%$ vs $12.8 \%)$, prior history of SIEs $(18.6 \%$ vs $5.8 \%$ ) and pulmonary disease $(10.2 \%$ vs $4.8 \%$ ). There were no differences in other clinical, demographic and medication history characteristics; steroid therapy was similar between the groups.

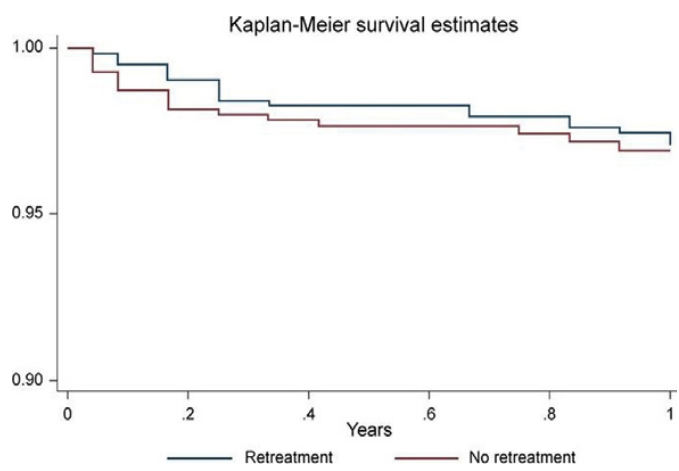

Conclusions: Retreatment with rituximab infusions was not associated with a higher rate of SIEs in this study. Patients who experienced an SIE had a higher prevalence of risk factors for infections.

References:

[1] Van Vollenhoven RF et al. J Rheumatol. 2015;42:1791-6.

Acknowledgements: This study is sponsored by Corrona, LLC. Corrona, LLC has been supported through contracted subscriptions in the last 2 years by AbbVie, Amgen, BMS, Crescendo, Eli Lilly, Genentech, GSK, Horizon Pharma USA, Janssen, Momenta Pharmaceuticals, Novartis, Pfizer, Roche and UCB. Disclosure of Interest: D. Pappas Grant/research support from: AbbVie, Consultant for: AbbVie, Employee of: Corrona, LLC, G. Reed Shareholder of: Corrona, LLC, Employee of: Corrona, LLC, S. Zlotnick Employee of: Genentech, Inc., J. Best Employee of: Genentech, Inc., R. Magner: None declared, G. Persuitte Employee of: Corrona, LLC, J. Greenberg Shareholder of: Corrona, LLC, Consultant for: Genentech; Janssen; Novartis; Pfizer; Eli Lilly, Employee of: Corrona, LLC DOI: 10.1136/annrheumdis-2017-eular.1752

\section{SAT0197 TREATMENT OUTCOMES WITH ANTI-TNF AND NON-ANTI-TNF DISEASE-MODIFYING THERAPY BY BASELINE BODY MASS INDEX}

E. Alemao $^{1}$, Z. Guo ${ }^{1}$, C. lannaccone ${ }^{2}$, M. Frits ${ }^{2}$, M. Weinblatt ${ }^{2}$, N. Shadick ${ }^{2}$ ${ }^{1}$ Bristol-Myers Squibb, Princeton; ${ }^{2}$ Brigham and Women's Hospital, Boston, United States

Background: Recent studies have indicated that being overweight or obese could reduce the effect of anti-TNF treatment in patients (pts) with RA. ${ }^{1,2}$ Other data show that certain biologic (b)DMARDs, such as abatacept, work independently of $\mathrm{BMI}^{3,4}$ Additional data on the role of BMI on treatment outcomes in clinical practice settings is required to inform clinical practice.

Objectives: To evaluate the impact of BMI on outcomes of disease activity in pts with RA treated with TNF and non-TNF agents (conventional or other bDMARDs). Methods: Pts enrolled in a tertiary care centre RA registry, established in 2003, were analysed. The registry mostly comprises pts with established RA who were evaluated semi-annually for multiple clinical patient-reported outcomes and resource utilization parameters, and annually for composite disease activity measures such as DAS28 (CRP), CDAI and SDAI. The current analysis is based on pts enrolled in the RA registry with $B M I$ values at time of enrolment. Pts were classified into groups based on BMl: normal (BMI $<25 \mathrm{~kg} / \mathrm{m}^{2}$ ), overweight (BMI $\geq 25$ to $<30 \mathrm{~kg} / \mathrm{m}^{2}$ ) and obese $\left(\mathrm{BMI} \geq 30 \mathrm{~kg} / \mathrm{m}^{2}\right.$ ). Outcomes evaluated included change from baseline in DAS28 (CRP), CDAI, SDAI and joint counts at 12 months 